\title{
LANDASAN FILOSOFIS PENDIDIKAN KARAKTER DI SD LUQMAN AL HAKIM TIMOHO YOGYAKARTA
}

\author{
Fitri Jamilah \\ Universitas Negeri Yogyakarta \\ fitrijamilah9@gmail.com
}

\begin{abstract}
Abstrak:
Pendidikan karakter sangat penting untuk melahirkan Sumber Daya Manusia yang berkualitas. SDM yang berkualitas yaitu yang memiliki karakter dan kepribadian berdasarkan tujuan pendidikan nasional. Saat ini nilai-nilai karakter telah terciderai oleh berbagai macam perilaku yang melanggar dari tujuan pendidikan. Artikel ini akan membahas bagaimana landasan filosofis pendidikan karakter di SD Luqman Al-Hakim. Artikel ini merupakan hasil penelitian kualitatif yang fokusnya untuk menginterpretasikan data yang telah didapatkan dengan penjelasan secara mendalam terhadap suatu fenomena yang diamati. Prosedur pengumpulan data yang dilakukan dalam penelitian ini yaitu observasi, wawancara, dan analisis dokumen. Analisis data dilakukan dengan mereduksi data, mengorganisasikan data, dan penyimpulan data. Hasil analisis data selanjutnya dicek keabsahannya melalui pemeriksaan triangulasi. Penelitian menekankan pada landasan filosofis pendidikan karakter yang diterapkan di SD Luqman Al-hakim yaitu humanis religius. Hal ini mengacu pada visi, misi, tujuan yang telah dirumuskan dan pelaksanaan pembelajaran. Pendidikan karakter mengintegrasikan antara aspek kauniyah (alam semesta) dengan aspek qauliyah (quraniyah).
\end{abstract}

Kata kunci: landasan filosofis, pendidikan karakter

\section{FILOSOPHICAL FOUNDATION OF CHARACTER EDUCATION IN SD IT LUQMAN AL HAKIM TIMOHO YOGYAKARTA}

\begin{abstract}
Character education is very important to give birth to qualified human resources which have characteristics and personality based on national education goals. At present the character values have been plagued by various kinds of behavior which violate the purpose of education. This article will discuss how the philosophical foundation of character education at SDIT Luqman Al-Hakim. This article is the result of qualitative research whose focus is to interpret the data which has been obtained with an in-depth explanation of an observed phenomenon. The procedure of data collection carried out in this study is observation, interviews, and document analysis. Data analysis is done by reducing data, organizing data, and concluding data. The results of the data analysis were then checked for validity through triangulation checks. The research emphasizes on the philosophical foundation of character education applied at SD Luqman Al-hakim, namely religious humanists. This refers to the vision, mission, objectives which have been formulated and the implementation of learning. This character education integrates the aspects of kauniyah (universe) with aspects of qauliyah (quraniyah).
\end{abstract}

Keywords: philosophical foundation, character education

PENDAHULUAN

Pendidikan karakter sangat penting untuk mencetak Sumber Daya Manusia yang berkualitas. (Arthur, 2008) menyatakan bahwa pendidikan karakter menggambarkan bagaimana anak 
bertumbuh menjadi pribadi yang memiliki karakter yang baik. Karakter yang baik tersebut tidak tumbuh secara otomatis, tetapi harus dibiasakan dan dibudayakan. Cerita tentang anak-anak mengalami bullying, sikap siswa yang tidak menghormati guru, orang tua yang menganiaya anak kandung, dan tindak korupsi yang dilakukan para pemimpin bangsa menjadi hal yang sangat menghawatirkan karena telah meciderai nilai-nilai pendidikan karakter. Data Global School-based Student Health Survey (GSHS) menunjukkan bahwa grafik kasus bullying di Indonesia mengalami peningkatan sejak tahun 2007, sekitar $40 \%$ murid berusia 13-15 tahun di Indonesia melaporkan telah diserang secara fisik di sekolah mereka. Laporan Komisi Perlindungan Anak Indonesia (KPAI, 2017) menunjukkan bahwa terdapat 3.849 kasus pelanggaran terhadap anak.

Sementara itu, tindakan korupsi di Indonesia juga cukup mengkhawatirkan. Devisi investigasi Indonesia Corruption Watch (ICW) menyatakan bahwa terdapat 576 kasus korupsi sepanjang tahun 2017. Indonesia Corruption Watch (ICW) menyatakan bahwa terdapat 576 kasus korupsi sepanjang tahun 2017. Berdasarkan data mengenai tindak kekerasan dan data tindak korupsi tersebut, maka bangsa Indonesia perlu berlu berbenah diri. Hal ini dikarenakan karena tonggak kemajuan bangsa, terletak pada SDM-nya.

Kemajuan suatu bangsa dapat ditinjau melalui kemajuan pendidikannya. Pendidikan merupakan metode fundamental dari kemajuan dan pembaruan sosial (Dewey, 1998). Pendidikan mampu membentuk pengetahuan dan sebuah ruang untuk mengembangkan keterampilan baik secara intelektual, emosional, dan sosial. SDM yang berkualitas akan terbentuk apabila proses pendidikan berjalan secara maksimal berdasarkan tujuan pendidikan nasional. SDM yang berkualitas adalah SDM yang memiliki kecerdasan secara intelektual dan juga memiliki karakter, akhlak dan budi pekerti yang baik. Karakter tumbuh dan terbentuk melalui kebiasaan dan pengaruh lingkungan. Lingkungan yang baik akan memberikan pengaruh yang baik, begitu pula sebaliknya.

Karakter juga dapat terbentuk melalui peniruan dalam interaksi di lingkungannya. Albert Bandura yang dikutip dalam Tarsono (2018: 30) menyatakan bahwa lingkungan memiliki pengaruh untuk membentuk karakter seseorang. Di samping itu, pada dasarnya manusia juga memiliki kemampuan untuk berpikir dan mengatur atau mengarahkan diri sendiri sehingga dapat mengontrol halhal yang terjadi di lingkungan. Dengan demikian, perilaku sebenarnya dapat dipelajari oleh seseoarng melalui interaksi dalam lingkungannya. Perkembangan kepribadian seseorang pun tergantung pada proses interaksi tersebut.

Pembinaan karakter lebih mudah dikembangkan saat usia anak-anak. Hal ini disebabkan anak-anak mudah menirukan hal-hal yang terjadi di lingkungan sekitarnya. Lickona (1992) mengembangkan pembelajaran nilai karakter/moral yang menyentuh beberapa aspek yaitu, konsep moral (moral knowing) mencakup kesadaran moral (moral awarness), pengetahuan nilai moral (knowing moral value), pandangan ke depan (perspective talking), penalaran moral (reasoning), pengambilan keputusan (decision making), dan pengetahuan diri (self knowledge). Sikap moral (moral feeling) mencakup kata hati (conscience), rasa percaya diri (self esteem), empati (emphaty), cinta kebaikan (loving the good), pengendalian diri (self control), dan kerendahan hati (and huminity). Prilaku moral (moral behavior) mencakup kemampuan (compalance), kemauan (will) dan kebiasaan (habbit).

Membentuk karakter diibaratkan seperti mengukir batu permata atau permukaan besi yang keras. Ukiran tersebut akan memberikan sebuah tanda dan membutuhkan proses yang tidak mudah. Farmer Bohlin dalam Judiani (2010) mengembangkan pengertian karakter yang 
diartikan sebagai tanda khusus atau pola perilaku. Menanamkan nilai-nilai karakter positif pada setiap anak berarti memberikan sebuah tanda dan pola perilaku yang baik. Menurut Pusat Bahasa Depdiknas, pengertian karakter adalah bawaan, hati, jiwa, kepribadian, budi pekerti, perilaku, personalitas, sifat, tabiat, temperamen, dan watak (Pasaribu, 2017: 317). Jadi dapat disimpulkan bahwa karakter itu erat kaitannya dengan personality.

Seseorang memiliki karakter yang baik apabila perilakunya sesuai dengan kaidah moral. Undang-Undang Sistem Pendidikan Nasional Nomor 20 Tahun 2003 menyebutkan pendidikan bertujuan untuk mengembangkan kemampuan dan membentuk watak serta peradaban bangsa yang bermartabat dalam rangka mencerdaskan kehidupan bangsa, bertujuan untuk berkembangnya potensi peserta didik agar menjadi manusia yang beriman dan bertakwa kepada Tuhan Yang Maha Esa, berakhlak mulia, sehat, berilmu, cakap, kreatif, mandiri, dan menjadi warga negara yang demokratis serta bertanggung jawab. UU tersebut menjelaskan bahwa seseorang/individu yang berkarakter baik atau unggul adalah seseorang yang berusaha melakukan hal-hal yang terbaik terhadap Tuhan Yang Maha Esa, dirinya, lingkungan, bangsa dan negara, serta dunia internasional pada umunya dengan mengoptimalkan potensi (pengetahuan) dirinya dan disertai dengan kesadaran, emosi dan motivasinya (perasaanya). Karakter itu lebih bersifat spontanitas maksudnya dalam bersikap atau melakukan perbuatan telah menyatu dalam diri manusia sehingga ketika muncul tidak perlu dipikirkan lagi.

Pendidikan karakter melalui pembelajaran perlu ditanamnkan sejak pendidikan dasar. Hal ini disebabkan pendidikan dasar menjadi fondasi dasar pendidikan jenjang selanjutnya. Pendidikan jenjang sekolah dasar tentunya masih belum banyak terkontaminasi dengan sifatsifat yang kurang baik, sehingga pendidikan karakter pada usia sekolah dasar akan memberikan peluang yang lebih besar bagi tertanamnya nilai-nilai karakter positif dalam diri peserta didik. Sekolah sebagai ruang pendidikan formal tentunya perlu memiliki visi, misi, dan tujuan yang dapat mengarahkan dan mengahsilkan SDM yang berkualitas. SDM yang tidak hanya cerdas secara intelektual, akan tetapi memiliki karakter sesuai yang telah dirumuskan di dalam UU.

Berdasarkan paparan di atas maka artikel ini akan membahas bagaimana bagaimana landasan filosofis pendidikan karakter di SD Luqman Al-Hakim Timoho Yogyakarta. Adapun tujuan penulisan artikel dimaksudkan untuk memberikan gambaran secara mendalam mengenai landasan filosofis yang dikembangkan, serta bagaimana implementasi pendidikan karakter di sekolah dasar tersebut sehingga dapat digunakan sebagai referensi para pembaca terutama para guru dan kepala sekolah ketika mengimplementasikan pendidikan karakter di sekolahnya masingmasing.

\section{METODE PENELITIAN}

Artikel ini merupakan hasil penelitian kualitatif, yang fokusnya lebih pada interpretasi terhadap data agar didapatkan penjelasan yang mendalam terhadap suatu fenomena yang diamati. Peneliti dalam penelitian ini bentindak sebagai instrumen kunci yang langsung terjun ke lapangan, karena peneliti sebagai instrumen utama dan bisa mengambil dan mengumpulkan data secara langsung di lapangan. Prosedur pengumpulan data yang dilakukan dalam penelitian ini yaitu observasi, wawancara, dan analisis dokumen. Analisis data dilakukan dengan mereduksi data, mengorganisasikan data, dan penyimpulan data. Hasil analisis data selanjutnya di cek keabsahannya melalui pemeriksaan triangulasi, pengecekan keanggotaan, kecukupan referensial, dan perpanjangan keikutsertaan. Proses pengumpulan data dalam penelitian ini melalui beberapa tahapan, yaitu: tahap persiapan, tahap pelaksanaan, dan tahap pelaporan. 
HASIL DAN PEMBAHASA Hasil

Sekolah Dasar Islam Terpadu (SDIT) Luqman Al-Hakim beralamatkan di Jalan Timoho II Gang Delima No 2 Umbulharjo Yogyakarta. SD IT Luqman Al-Hakim adalah sekolah dasar yang mengedepankan pembinaan akhlak dalam setiap pembelajarannya. SD tersebut memiliki 24 ruang dengan masing-masing memiliki empat ruang kelas paralel. SD IT Lukman Alhakim memiliki 70 tenaga pengajar dan 800 peserta didik. Ciri khas dari SD IT Luqman Al-Hakim adalah kurikulum yang digunakan adalah kurikulum terpadu. Kurikulum ini mengintegrasikan antara aspek kauniyah (alam semesta) dengan aspek qauliyah (quraniyah) yang diimplementasikan dalam pelajaran baik materi maupun proses Kegiatan Belajar Mengajar (KBM). Penyelenggaraan KBM dilaksanakan secara full day dari pukul 07.15 sampai dengan 15.30 WIB. Setiap siswa, guru, dan karyawan di sekolah tersebut diharuskan untuk everyday with alquran, yaitu menjadikan alquran menjadi bacaan harian baik di sekolah maupun di rumah dan mentadaburinya sehingga diharapkan siswa setelah lulus mampu menghafalkan Alquran minimal 3 Juz.

Visi dari SD IT Luqman Al-Hakim Yogyakarta adalah "Terwujudnya Generasi yang Qurani, Mandiri, Berprestasi, dan Berbudaya Lingkungan. Visi tersebut memuat indikator yaitu: 1) Mempunyai akidah, ibadah, dan akhlak sesuai tuntutan Alquran, 2) Tumbuh kesadaran untuk belajar tertib, disiplin, hemat, dan tanggung jawab, 3) Tuntas dalam pencapaian akademik serta terbina minat dan bakatnya, 4) Peduli terhadap lingkungan sekitar. Sedangkan Misi dari SDIT Luqman AlHakim yaitu: 1) Menyelenggarakan pendidikan Alquran di dalam intrakurikuler, ekstrakurikuler, kepesantrenan, dan program pembiasaan; 2) Menyelenggarakan pendidikan yang menumbuhkan kesadaran untuk belajar tertib, disiplin, hemat, dan tanggung jawab;
3) Menyelenggarakan pembelajaran yang aktif, inovatif, islami, kreatif, efektif, dan menyenangkan, dan pembinaan siswa secara intensif untuk meraih prestasi; dan 4) Menyelenggarakan pembelajaran dan pembiasaan peduli lingkungan.

Tujuan yang dimiliki SD IT Luqman Alhakim adalah membina peserta didik untuk mempunyai dasar-dasar menjadi insan muttaqien yang cerdas, berakhlak mulia, dan memiliki keterampilan yang memberi manfaat dan maslahat bagi umat manusia dan lingkungannya dengan rincian karakter sebagai berikut.

1. Pribadi Qurani, yaitu memiliki akhlak dan kepribadian sesuai dengan yang dituntunkan dalam Alquran, menjadi anak soleh dan solehah.

2. Memiliki aqidah yang kuat dengan meyakini bahwa hanya Allah-lah pencipta, pemilik, pemelihara dan penguasa alam semesta.

3. Terbiasa melaksanakan ibadah yang meliputi: solat, shaum (puasa), tilawah alquran, dzikir, dan doa sesuai petunjuk Alquran dan As-Sunnah.

4. Akhlak yang matang dan terpuji, menampilkan perilaku yang santun, tertib, dan disiplin, peduli terhadap sesama dan lingkungan, serta sabar, ulet, dan pemberani dalam menghadapi permasalahan hidup sehari-hari.

5. Mandiri

6. Tertata urusan, tertib dalam menata segala kegiatan tugas dan kewajiban, sertacermat dan penuh perhitungan dalam melangkah.

7. Cermat waktu, selalu memanfaatkan waktu dengan kegiatan yang bermanfaat dan mampu mengatur jadwal kegiatan sesuai dengan skala prioritas.

8. Jiwa kewirausahaan, memiliki bekal dalam pengetahuan, kecakapan dan keterampilan dalam usaha memenuhi kebutuhan hidupnya.

9. Kesungguhan dan keberanian, memiliki kesungguhan dan motivasi yang tinggi dalam memperbaiki diri dan lingkungannya yang ditunjukkan dengan 
etos dan kedisiplinan kerja yang baik dan berani dalam mengambil resiko.

10. Berprestasi

11. Wawasan luas, memiliki kemampuan berpikir yang kritis, logis, sistematis, dan kreatif, yang menjadikan dirinya menguasai bahan ajar dengan sebaikbaiknya dan berpengetahuan luas, serta cerdik dalam mengatasi segala problem yang dihadapi.

12. Fisik yang kuat, memiliki badan dan jiwa yang sehat dan bugar, stamina daya tahan tubuh yang kuat untuk mendukung keberhasilannya, serta memiliki keterampilan beladiri yang cukup untuk menjaga diri dan kejahatan pihak lain.

13. Berkepribadian lingkungan, bermanfaat bagi lingkungan, baik lingkungan sekolah, masyarakat, bangsa, maupun dunia internasional, dan menjauhi tindakan-tindakan yang anarkis.

Ide dasar SD IT (Sekolah Dasar Islam Terpadu) Luqman Al-Hakim berangkat dari berkembangnya SDIT dari sejak akhir tahun 1980-an yang sangat marak di Indonesia. SD IT adalah sebuah wacana dari para penggagas karena melihat kejanggalan sekolah-sekolah nasional yang mendidik anak sekuleristik dengan memisahkan kehidupan keagamaan dengan kehidupan sosial bermasyarakat. Ada beberapa sekolah Islam yang merupakan sekuleristik yang pembelajarannya hanya fokus dalam ibadah-ibadah dan mengenyampingkan ilmu pengetahuan. Hal ini berdampak terpuruknya umat islam dalam bidang ilmu pengetahuan dan teknologi.

SDIT Luqman Al-Hakim menerapkan pendidikan Islam terpadu dalam sistem pengajarannya, artinya bagi siswa SD IT mereka sudah diajari sekaligus mengamalkan ajaran Islam dalam keseharian, mulai dari perilaku sampai pada pengamalan atau penerapan langsung ajaran Islam. Proses pembelajaran dikemas dalam bentuk training, penunh dengan game-game terkait mata pelajaran bahkan selalu ada yel-yel sebagai pemelihara semangat setiap lima belas menit sekali. Di samping itu pendidikan karakter yang dikembangkan dalam kurikulum adalah Islam sebagai landasan filosofis.

Nilai-nilai Islam menjadi inspirasi dan sekaligus pemandu utama dalam penyelenggaraan pendidikan di SD IT tersebut. Pendidikan Islam akan mampu:

1. Membentuk sikap dan kepribadian yang kuat berdasarkan prinsip-prinsip keilahian, dengan aqidah yang benar, seorang muslim akan mampu menunjukkan sikapnya yang tegar, sabar, istiqomah, serta selalu berpihak dan membela yang haq.

2. Memompa semangat keilmuan dan karya. Islam mengajarkan pemeluknya untuk selalu berpikir dan berkarya. Doktrin Islam adalah "sebaik-baik manusia adalah manusia yang memberi manfaat bagi orang lain".

3. Membangun karakter/pribadi yang saleh yaitu selalu menegakkan nilai-nilai dan praktik ibadah. Dengan perilaku ibadah yang bersih, niscaya akan terbentuk karakter muttaqien, selalui menjauhi perilaku negatif.

4. Membangun sikap peduli kepada orang lain, hewan, dan lingkungannya, serta memecahkan permasalahan sosial.

5. Membentuk pandangan yang visioner, berpikir, bekerja, dan bertindak untuk kepentingan masa depan.

\section{Pembahasan}

Visi SDIT Luqman Al Hakim terdiri dari 4 yaitu: "Terwujudnya Generasi yang Qurani, Mandiri, Berprestasi, dan Berbudaya Lingkungan. Empat visi sekolah SDIT tersebut menjelaskan bahwa SDIT Luqman Al Hakim menempatkan pembinaan karakter Alquran sebagai pembentukan kepribadian di lingkungan sekolah baik kepada peserta didik maupun komponen pendidikan yang lain. Visi yang telah dirumuskan dan untuk mewujudkan visi tersebut SDIT merumuskan Misi yaitu: 1) Menyelenggarakan pembelajaran $\mathrm{Al}$ Quran secara intrakurikuler dan ekstrakurikuler (kepesantrenan), serta 
program pembiasaan, 2) Menyelenggarakan pendidikan yang menumbuhkan kesadaran untuk belajar tertib, disiplin, hemat, dan tanggung jawab (pendidikan karakter, 3) Penyelenggaraan pembelajaran aktif, inovatif, islami, kreatif, efektif dan menyenangkan (PAIIKEM), 4) Menyelenggarakan pembelajaran dan pembiasaan peduli lingkungan. Keempat misi tersebut bagian dari strategi yang diterapkan di SDIT Luqman Al-Hakim.

Ciri khas yang dimiliki oleh SDIT Luqman AL Hakim adalah (1) menerapkan sistem integrated curricullum atau kurikulum terpadu yaitu berusaha mengitegrasikan aspek kauniyah (Iptek) dengan Qauliyah (Alquran) yang diimplementasikan dalam pelajaran baik materi maupun proses KBM-nya. Hal ini didasarkan pada 13 tujuan yang telah dirumuskan. Kurikulum yang diterapkan mengkolaborasikan antara kurikulum 2013 dan kurikulum muatan Islam terpadu. Pembelajaran yang dilakukan tidak hanya mengembangkan aspek pengetahuan dan keterampilan umum, akan tetapi juga mengedepankan aspek nilai-nilai Islam. Hal ini diwujudkan dalam program Everyday with Quran sehingga target yang diharapkan siswa ketika lulus nanti telah hafal minimal tiga Juz dari Al Quran. Communicative stimulative, maksudnya adalah menjalin hubungan antara pihak sekolah, orang tua dan siswa dalam rangka kesesuaian antara program pendidikan yang dilakukan di sekolah dengan yang dilakukan di rumah.

Berdasarkan visi, misi, tujuan dan proses pembelajaran, maka landasan filosofis yang diterapkan di SDIT Luqman Al-Hakim adalah humanis religius. Sistem dan suasana pendidikan yang dibangun di sekolah tersebut melibatkan semua satuan pendidikan, baik kepala sekolah, guru, staf, siswa, orang tua, bahkan lingkungan sekitar. Berdasarkan hasil observasi dan wawancara yang telah dilakukan maka pengembangan budaya kehidupan yang humanis religius di SDIT Luqman AlHakim terwujud dalam hal-hal yaitu: pertama, membangun visi lembaga yang mengandung nilai humanis religius. Visi adalah mimpi dan cita-cita lembaga yang ingin dicapai. Oleh karena itu menguatkan visi adalah upaya awal yang harus dilakukan. Kedua, menetapkan misi dan tujuan yang tampak jelas memiliki nilainilai humanis religius. Dengan menetapkan visi, misi, dan tujuan maka semua sivitas akademika akan lebih fokus untuk membangun dan mengembangkan nilai tersebut. Misalnya nilai religiusitas, kedisiplinan, kerja keras, kejujuran, dan rasa ingin tahu. Ketiga, menciptakan suasana lingkungan sekolah yang damai. Kedamaian dan kebahagiaan adalah ruhnya kehidupan. Program apapun yang diselenggarakan tentu jangan sampai merenggut kedamaian dan kebahagiaan yang semestinya dinikmati oleh siswa. Siswa akan lebih mampu mengaktualisasikan potensi yang ada bila dalam suasana yang damai tanpa tekanan, ancaman, dan suasana takut. Keempat, membangun lingkungan sekolah yang lebih kondusif. Lingkungan memberi pengaruh amat besar bagi keberlangsungan lembaga. Lingkungan yang kondusif memberikan kekuatan tersendiri bagi sekolah untuk mencapai hasil. Oleh karena itu sebagian dari tugas sekolah adalah turut membina lingkungan. Kelima, bekerja sama dan bersinergi dengan lingkungan sosial. Hal itu akan meringankan tugas sekolah dalam membimbing dan mengarahkan siswa menjadi lebih baik. Sekolah tidak boleh berkembang sendiri dan terlepas dari lingkungan sosialnya.

\section{SIMPULAN}

Berdasarkan hasil penelitian dan pembahasan yang telah diuraikan di atas, maka dapat diambil kesimpulan yaitu landasan filosofis yang diterapkan dengan mengacu visi, misi, tujuan dan pelaksanaan pembelajaran adalah humanis religius. Di samping itu, juga tercermin pada kurikulum yang dikembangkan yaitu dengan mengintegrasikan antara aspek kauniyah (alam semesta) dengan aspek qauliyah 
(quraniyah) yang diimplementasikan dalam materi pembelajaran maupun proses Kegiatan Belajar Mengajar (KBM).

Pendidikan karakter yang ingin dibangun adalah peserta didik pada akhirnya mempunyai dasar-dasar untuk menjadi insan muttaqien yang cerdas, berakhlak mulia, dan memiliki keterampilan yang memberi manfaat dan maslahat bagi umat manusia dan lingkungannya.

\section{Daftar Pustaka}

Arthur, . 2008. Traditional Approaches to Character Education in Britain and America. New York: Routledge.

Dewey, J., terj. Zainuddin, A. R. (1998). Budaya dan Kebebasan. Jakarta: Yayasan Obor Indonesia.

Lickona, T. (1992). Educating for Character, How Our Schools Can Teach Respect and Responsibility. New York: Bantam Books.

Judiani, Sri. 2010. "Implementasi Pendidikan Karakter di Sekolah Dasar melalui Penguatan Pelaksanaan Kurikulum". Dalam Jurnal: Pendidikan dan Kebudayaan, Volume 16, No 3.

Jumarudin, dkk. 2014. "Pengembangan Model Pembelajaran Humanis Religius dalam Pendidikan Karakter di Sekolah Dasar. Dalam Jurnal: Pembangunan Pendidikan:Fondasi dan Aplikasi, Volume 2, Nomor 2.

Pasaribu, S. A. 2017. "Pendidikan Karakter Anak Usia Dini". Prosiding Seminar Nasional Tahunan Fakultas Ilmu Sosial Universitas Negeri Medan Tahun 2017.

Tempo. 2018. "Kasus Korupsi Tahun 2017, ICW: Kerugian Negara Rp 6,5 Triliun".

https://nasional.tempo.co/read/1062 534/kasus-korupsi-tahun-2017-icwkerugian-negara-rp-65-

triliun/full\&view $=$ ok

Diakses

Tanggal 2 Desember 2018.

Tarsono. 2018. "Implikasi Teori Belajar Sosial (Social Learning Theory) dari Albert Bandura dalam Bimbingan dan Konseling". Dalam Jurnal: Psympatic, Jurnal Ilmiah Psikologi, Volume 3, Nomor 1.

Wododo, Hendro. 2018. "Pengembangan Respect Education melalui Pendidikan Humanis Religius di Sekolah. Dalam Jurnal: Lentera Pendidikan, Volume 21, No 1. 